\title{
The Role of Farmer's Cooperatives in Honey Production and Marketing: The Case of Masha Woreda South- West Ethiopia
}

\author{
Metages Belete \\ Wolaita Sodo University College of agriculture department of agribusiness and value chain management, \\ PO Box: 138, Wolaita Sodo University, Ethiopia
}

\begin{abstract}
This study examined the role of honey producer farmer's cooperative in Masha District south-west Ethiopia. The data were collected through Questionnaire, Interview and focus group discussion. Both primary and secondary data were taken for this study. There were six honey producing farmers cooperative with 215 members in the study area. All of the cooperatives and member farmers were sampled for this study. The study used primary data from cooperative members' household survey, and focus group discussion to provide background information and investigate the role of the cooperatives in honey production and marketing and constraints regarding honey production and marketing. Secondary data are also used to supplement primary data. The analysis is carried out by applying more of explanatory, descriptive and qualitative means of analysis. As a result, the study identified those constraints which affect the cooperatives production and marketing potential such as; lack of members commitment, limited leadership and management capacity, inadequate working capital, lack of inputs, lack of government and NGO support, lack of infrastructure facilities, limited training opportunities and storage problem. Even if the cooperatives do have a great potential to increase the honey productivity, due to the existence of these constraints, they didn't bring significant progress yet in the study area. To minimize the impact of their constraints, cooperatives are expected to enhance transparency and accountability. In addition cooperatives are expected to strengthen their members' equivalent participation together with its controlling mechanism to enhance the number of members which actually contributes for the increased honey productivity. As lack of working capital is also one of the problems of cooperatives, they are expected to effectively mobilize members for additional share capital contribution and credit access. If integrated corrective actions are taken on these identified constraints of cooperatives by members and stake holders, the cooperatives will play significant role on honey production and marketing in the study area.
\end{abstract}

Keywords: farmers cooperative, honey production and marketing, constraints

DOI: $10.7176 / \mathrm{DCS} / 9-8-01$

Publication date: August 31st 2019

\section{Introduction}

\subsection{Background of the study}

The International Cooperative Alliance (ICA, 2010) defined a cooperative as "an autonomous association of persons united voluntarily to meet their common economic, social and cultural needs and aspirations through a jointly - owned and democratically controlled enterprise". The definitions of cooperative societies are often supplemented with the distinguishing features of seven cooperative principles adopted by ICA. These are: voluntary and open membership, democratic member control, member economic participation, autonomy and independence, education, training and information, cooperation among cooperatives, and concern for community. Cooperative societies function on the basis of the values of self-help, self-responsibility, democracy, equality, equity and solidarity. In the tradition of their founders, cooperative members believe in the ethical values of honesty, openness, social responsibility and caring for others (ICA, 1995).

Cooperative activity in agricultural production is encouraged among farmers. Cooperatives all over the world are instruments of social and economic transformation (Ijere, 1992). The relevant social aspects of people from Africa, according to Ijere (1992) are those aspects that deal with their attitudes to life and themselves, their modes of behavior and relationship with one another as well as their customs. People come together to help themselves. That is to say, that individuals form groups or cooperatives to complement their individual efforts geared towards solving economic problems such as scarcity of goods and services, matching wants with available resources and seeking ways to augment any short fall or optimizing the given situation by different types of combinations (Ijere, 1992).

Co-operation as a way of life has been and continues to be a tradition in finding the solution to the socioeconomic problems of the people in Ethiopia. Examples of such cooperation can be found everywhere in the working of mutual aid institutions such as Equb, Eddir, Wonfel or Jigii, Senbete and many others. The traditional cooperation among the rural community was a ground to the flourishing of modern cooperation in early 1960s, realizing that these traditional institutions failed to meet the requirements of credit services and equipment needed for productive purposes in full. In all circumstances the program for cooperative development was, therefore, formulated and had been included in the second Five-year Development plan (1962-67) of the country (Zerihun, 
1998).

Collective action groups, in particular, modern cooperatives, have gained due attention in development discourse and programs designed for poverty reduction in Ethiopia (Emana 2012). The Ethiopian government believes cooperatives as important vehicles for the implementation of different development programs mainly in the agricultural sector (Emana and Nigussie 2011, MoA 2012), since agriculture which is dominated by smallholder farmers determines the growth of all other sectors and consequently of the entire economy in Ethiopia (Gebre-selassie and Bekele 2012, MoA 2012).

In Masha woreda there are 6 farmer's cooperatives which are directly participating in honey production and marketing. Therefore this study is designed to investigate the role of the cooperatives in honey production and marketing in the study area.

\subsection{Objectives}

\subsubsection{General objective}

To analyze the role of farmer's cooperative in honey production and marketing in Masha woreda, Ethiopia.

\subsubsection{Specific objectives}

1. To assess the role of cooperatives in honey production and marketing

2. To identify honey production and marketing constraints of cooperatives

\section{Methodology of the study}

This study was conducted in Masha Woreda. Sheka Zone has three Woredas (districts), namely Masha, Andiracha and Yeki. In total the Zone has 56 rural Kebeles, 5 urban Kebeles and 2 chartered towns or city administrations, Teppi\& Masha. More specifically, Masha is the administration center of ShekaZone and is located $676 \mathrm{~km}$ southwest of Ethiopia from Addis Ababa along Addis-Jimma road. This Woreda is bordered on east by GeshaWoreda of Keffa Zone, on west by Sele- NonnoWoreda of Oromia region, on south by Diddo-LalloWoreda of Oromia region and on north by AndrachaWoreda of Sheka Zone. The Woreda has a total land area of about $90,802.82$ hectares. Out of this land area about $23.9 \%$ is cultivated, $2.8 \%$ is grazing land, $40.5 \%$ is covered by forest, $5.5 \%$ arable land, $5.9 \%$ non-arable land and $21.4 \%$ is settled land area. This Woreda lies between $1600-$ $2400 \mathrm{~m}$ above sea level and receives $2000 \mathrm{~mm}$ rainfall. Agro climatically, the area is largely Woinadega type comprising about $75 \%$ of the total area, $22 \%$ and $3 \%$ are in Dega and kola types.

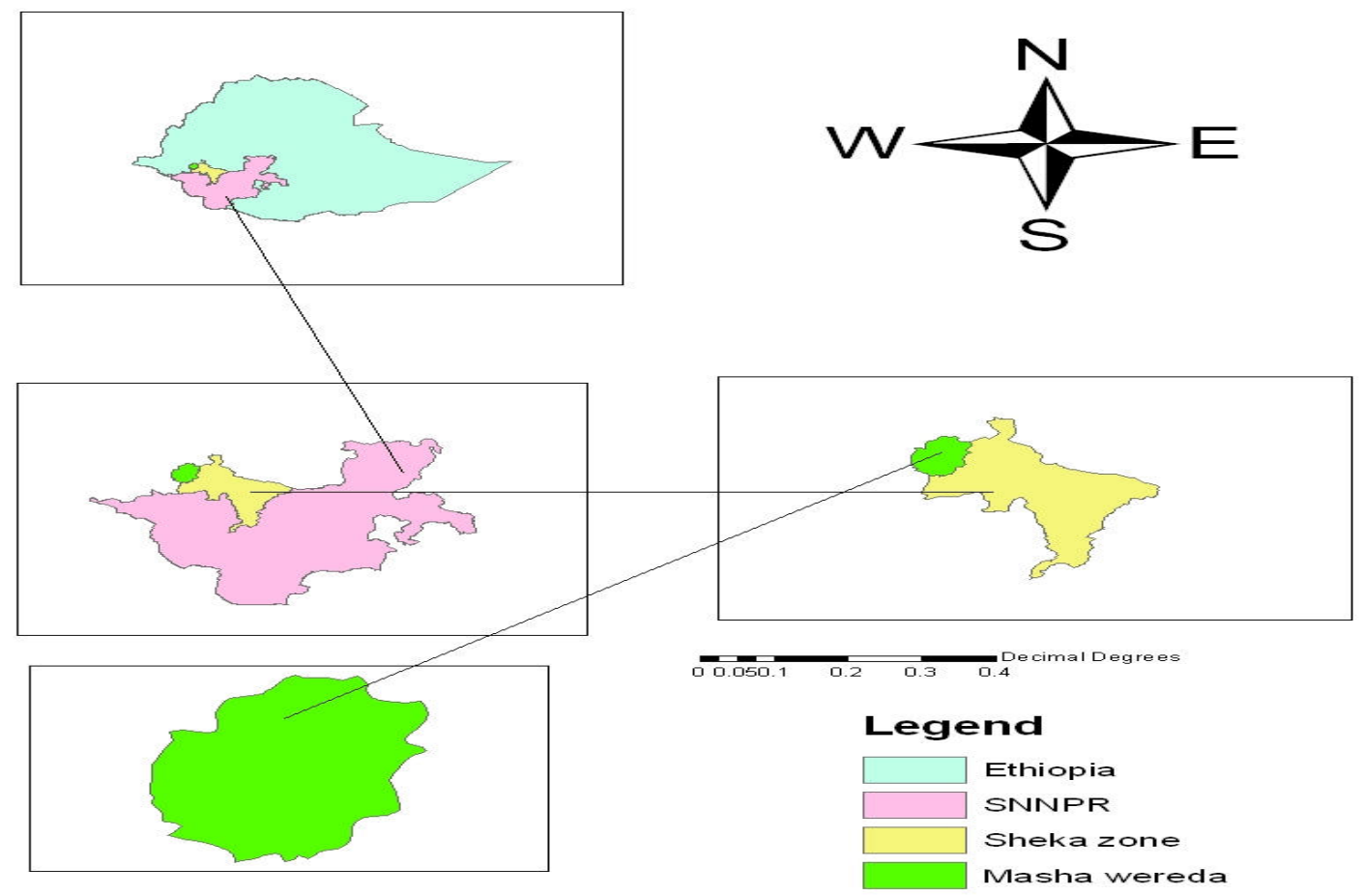

Fig.1. Map of the study area 


\subsection{Sample size determination}

This study was conducted in 6 farmers cooperatives which were directly participated in honey production and marketing in the study area. The following table shows the total number of cooperative members:

Table 1: Honey producer and marketing cooperatives

\begin{tabular}{|l|c|c|c|c|}
\hline \multirow{2}{*}{ Cooperative name } & \multirow{2}{*}{ Kebele } & \multicolumn{3}{|c|}{ Members } \\
\cline { 3 - 5 } & & Men & Women & Total \\
\hline Grawina & Beto & 23 & 9 & 32 \\
\hline Gedaemi & Woloshoba & 33 & 2 & 55 \\
\hline Wododinbarona & Woloshoba & 30 & 20 & 22 \\
\hline Wondimamachoch & Chago & 15 & 7 & 25 \\
\hline Matiganity & Abelo & 21 & 20 & 51 \\
\hline Yerishunity & Chago & 31 & 62 & 215 \\
\hline Total & & 153 & 2 & 50 \\
\hline
\end{tabular}

The data for this study was collected from all cooperative members. So, the sample size of the study was all of 215 individual cooperatives members.

\subsection{Type, source and method of data collection}

Both qualitative and quantitative data were used to find the relevant information for the study. The data were collected from both primary and secondary sources. Questioner, interview and checklist were used to get first hand information from the sample respondents. The secondary sources of data were journals, books, internets browsing, and different reports. While primary data sources includes agricultural office, Marketing and cooperative office, trade and industry office, finally, focus group discussion with cooperative management bodies were conducted.

\subsection{Method of data analysis}

After the collected data were coded, entered and edited then analyzed by using explanatory, descriptive and qualitative means of analysis.

\section{Result and discussion}

\subsection{Demographic characteristics of the respondents}

The total respondents for this study were 215 . Out of 215 respondents $153(71.2 \%)$ were male and $62(28.8 \%)$ were female. In the study area beekeeping is practice in dense forest areas by hanging the beehives in large trees and this practice is hindering the females to participate in honey production therefore few women's are involved. According to the data gathered from the respondents the participated women are single, widowed and divorced. The data showed that $29(13.5 \%)$ respondents were single, $126(58.6 \%)$ were married, 31(14.4\%) were widowed and $29(13.5 \%)$ were divorced. Regarding the education level of the respondents $152(70.7 \%)$ were literate and $63(29.3 \%)$ were literate. The mean age of members of households involved in beekeeping is 45 years (maximum 70 and minimum 20).

\subsection{Cooperatives role in honey production and marketing}

\subsubsection{Beehive construction and honey production}

According to the respondents beekeeping is undertaken by three types of bee hives: - traditional, intermediate and Zander model box hives. The traditional hive beekeeping practice is the dominant system accounting for more than $75 \%$ of the total, while intermediate and modern hives are less used $(<25 \%)$. Only very few cooperative members reported having intermediate hive that has been supplied by different Non Governmental Organizations like MELCA mahiber Ethiopia, Non Timber Forest Products Project (NTFP) and Zonal and Woreda Agricultural development and marketing and cooperative office.

According to the survey result 2, 5 and 85 were the average number of modern, transitional and traditional hives household of the cooperative members. Of the total owned traditional hives, $<50 \%$ of the hives was found occupied by bees while the rest were empty. Mean productivity of crude honey from one beehivelyear was $15 \mathrm{~kg}$ (ranging from $5-25 \mathrm{~kg}$ ), $19 \mathrm{~kg}$ (ranging from $8-30 \mathrm{~kg}$ ) and $25 \mathrm{~kg}$ (ranging from $15-35 \mathrm{~kg}$ ) for traditional, transitional and modern beehives. In the study area the majority of farmers construct their traditional beehives from different locally available plants locally called, hareg (Solanecoangelatus) and bamboo. Traditional hives have a cylindrical shape with a length of 0.75 to 1.5 meters. Constructing and hanging of traditional beehives are made exclusively for men due to its cumbersome nature and culture.

According to the survey result $76.5 \%$ of the respondents were used only traditional beehives and keeping bees in the forest by hanging the hive on long trees in dense forests and $13.9 \%$ of the respondents were used both traditional and transitional types of beehives. While, the rest $9.6 \%$ of respondents are using both traditional, transitional and improved beehives in the study area. 


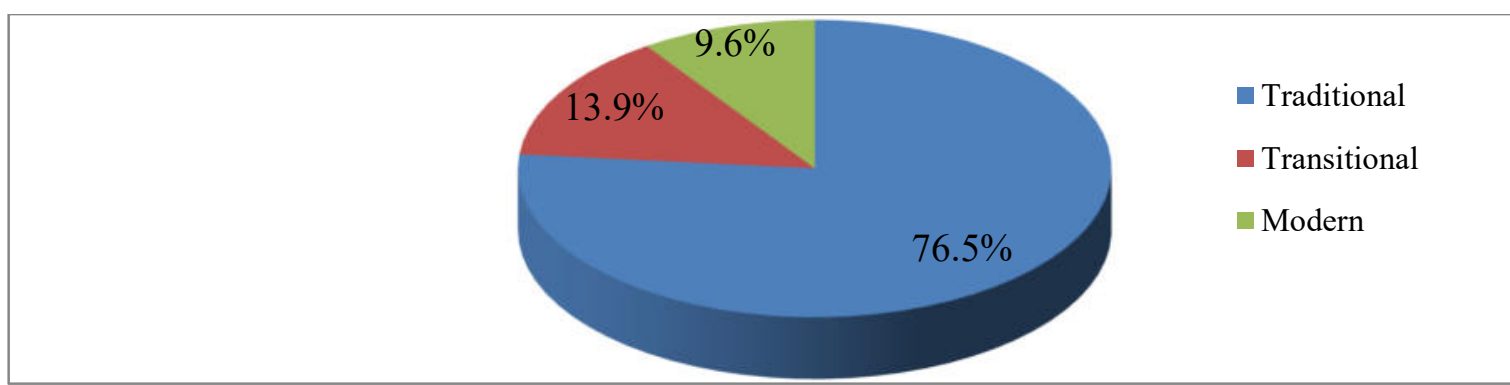

Fig 2: beehive types by the respondents in percentage

\subsubsection{Honey harvesting}

In Ethiopia, there are generally two honey harvesting seasons: the major one that lasts from October to November and the secondary one from April to June. However, in addition to these major harvesting periods, there are many small harvesting periods which depend on the type of flowering plants and rainfall patterns in different agroecologies (Adgaba, 2007), which experienced beekeepers and local people easily associate the harvesting season with the botanical origin of honey in their locality (Legesse, 2013).

Farmers in the study areas have experiences to know whether honey is ripened for harvesting or not. Appearance of high population of bees at the entrance of the hive, increasing of the defensiveness of bees, and completion of flowering periods of honey plants in the surrounding areas are some of the indicators for honey ripening. During harvesting all respondents mainly use animal dung smoke to subdue and push away the bees. Some also smoke Teff straw for the same purpose. In the study area there are two honey harvesting periods such as April to June and September to October, of which the former is the peak harvesting period contributing majority of the annual honey production.

\subsubsection{Honey processing and marketing}

Cooperatives sale the crude honey they bought directly from members to their respective unions which process and pack honey for export market by extracting liquid honey from the honey comb and to local breweries. In addition, cooperatives semi-process and pack honey by themselves and sell to the local consumers at their own retailing shop. Cooperatives also jointly working with beekeepers households and give trainings on bee forage development, queen rearing, harvesting and processing honey in the study area. Two cooperatives were registered by ILO in 2007 on fare trade though Beza Mar Company and they get 0.2 dollar premium price honey sold. This premium price used by the cooperatives for different development activities in the area.

\subsection{Honey production and marketing constraints of cooperatives}

The respondents in the study area were identified many problems in honey production and marketing which hinder their potential. The followings are less important, important and very important constraints according to the respondents:

Table 2: Constraints of honey production and marketing

\begin{tabular}{|l|l|l|l|l|l|l|}
\hline \multirow{2}{*}{ Constraints } & \multicolumn{2}{|c|}{ Less important } & \multicolumn{2}{c|}{ Important } & \multicolumn{2}{c|}{ Very important } \\
\cline { 2 - 7 } & Frequency & $\%$ & Frequency & $\%$ & Frequency & $\%$ \\
\hline Lack of member's commitment & 36 & 16.7 & 146 & 68 & 33 & 15.3 \\
\hline Lack of inputs & 20 & 9.3 & 150 & 69.8 & 45 & 20.9 \\
\hline Limited leadership and management capacity & 27 & 12.6 & 136 & 63.2 & 52 & 24.2 \\
\hline Lack of governmental and NGO support & 42 & 19.5 & 127 & 59 & 46 & 21.5 \\
\hline Inadequate working capital & 23 & 10.7 & 134 & 62.3 & 58 & 27 \\
\hline Lack of infrastructure facilities & 37 & 17.2 & 130 & 60.5 & 48 & 22.3 \\
\hline Limited training opportunities & 40 & 18.6 & 123 & 57.2 & 52 & 24.2 \\
\hline
\end{tabular}

Lack of inputs: Different types of inputs are needed to produce honey. Such inputs includes: modern beehives, protective materials, honey extractor, honey presser, bee brush, kilograms, packaging materials and others. According to the respondent's (as shown in table 2, 69.8\%) lack of inputs are the major constraints in their production. Almost all beekeepers practice traditional beekeeping in the study area. According to the respondents, there is very low provision of improved beehives from governmental and nongovernmental organizations and it is expensive to purchase the modern beehive. Due to this problem, the productivity and quality of honey become low.

Lack of member's commitment: As the result of this study ( as shown in table 2, 68\%) the sample respondents agreed that failure of members to involve in general meeting, poor participation in decision-making and limitation in exercising their democratic right were the most important problems to determine the performances of the cooperatives. This result in addition indicates that, the highest result was failure of members to attend the annual 
general meeting. According to the FGD members can only have the opportunities to elect boards, approve annual budget and activities, and evaluate the audit as well as activities report in the annual meeting. If they failed to attend the meeting, they might not have a power to make decisions and opportunities to exercise their democratic right.

Limited leadership and management capacity: Among the total member respondents (on table 2) 63.2\% of them responded as the currently existing management committee have limited capacity to effectively lead the cooperatives. This result implies the management committees have limited capacity to plan, implement and monitor the overall cooperative activity by mobilizing the members. The problem was caused because of the rural area have shortage of skilled and educated ma $\mathrm{n}$ power. The respondents interviewed from focus group discussion confirmed that lack of skilled and motivated leadership was the major factor hindered cooperatives development in the study area.

Lack of governmental and non- governmental organization support: Governments can help cooperatives spread from grass roots, local organization to a national network by providing organizational expertise and a large infusion of capital. Foreign aid donors can contribute their expertise to this process. In the study area the governmental and non-governmental organization support was not as expected, even if the total policy and frame works is supportive. The study shows that government provides some technical and financial assistance to cooperatives through Masha woreda cooperative office and non-governmental organizations like MELCA Ethiopia, NTFP and Beza Mar Company provide training and other beekeeping inputs. In general regarding to government support we can say that it was not adequate for overall development of cooperatives in the study area. Inadequate working capital: The result of this study indicates that (as seen in the table 2) for t he question asked concerning lack of financial resources, of which $62.3 \%$ of the respondent agreed there was lack of financial resources. Of course, although, resources are always scarce in every aspect but wise utilization of the existing resources are more important to achieve better result. Working capital allows cooperatives to grow in the future. When a cooperative desires to grow or is trying to meet customer demands, it often purchases additional assets needed to produce products at a quicker pace and on a larger scale. A lack of working capital hinders cooperatives from acquiring what it needs to expand.

Lack of infrastructure facilities: For all cooperative infrastructure facilities such as road, electricity, communication and others have important role. However, the study shows that poor infrastructural facilities in the area were major problem hindered cooperatives development. Especially road problem were a serious problem to transport the product to the cooperative office because in the study area beekeeping is undertaken in the forest.

Limited training opportunities: Even if it is the duty of the cooperative promotion office, being with other concerned bodies, to capacitate the management bodies of the cooperatives, majority of the participants in this focus group discussion reported that they get capacity building training rarely. Hence, the management committee members have weak management capacity. As a result they fail to evaluate the performance of their society and take corrective actions.

Storage problem: According to the FGD Most of the cooperatives do not have storages or warehouses owned by them. While those few cooperatives who do have storage are below the required standard. Inadequate size or capacity, unevenly leveled floor, holes on the walls, floor and roof were the most important problems of the stores. This will expose the honey product of the cooperatives for the decreasing of their honey product and quality due to humidity.

\section{Conclusion and recommendation}

4.1. Conclusion

Cooperative is an important tool for better living since enable the individual to achieve heights which cannot be reached in isolation. Agricultural cooperatives operate in the agricultural sector of the national economy and they are supposed to play their role in the agricultural production and marketing system and promote agricultural development in the rural area. This study was done with cooperatives participating in honey production and marketing in Masha woreda of Shaka zone, Ethiopia. Masha Woreda is well known by its long tradition and culture of beekeeping. The availability of dense natural forest and flowing plants makes mash District and its surrounding area fertile zone for honey production and marketing. According to Awraris et. al (2012) investigation the 50 percent Masha district economy rely on honey production and marketing. Honey is the number one cash crop in the study area. However, mainly due to lack of improved bee keeping technologies and weak market linkage development problems the Woreda honey producers in general and the cooperative members in particular have not been sufficiently benefited from the sub sector. Therefore, this study was conducted in cooperatives role in honey production and marketing with the specific objectives: assessment of the role of cooperatives in honey production and marketing and identification of cooperatives constraints in honey production and marketing in the study area. Based on the result of members perception and FGD on their cooperatives the study concluded as follow:

More than $75 \%$ respondents were used the traditional type of beekeeping by constructing with local found 
materials. $<25 \%$ respondents were used an intermediate and modern types of beehives. The production of honey is undertaken by hangings the beehives in the long trees in the dense forest.

April to June and September to October are honey harvesting season according to the respondents but, April to June is the peak harvesting season. Majority of respondents mainly use animal dung smoke to subdue and push away the bees. Some of the respondents also smoke Teff straw for the same purpose to harvest the honey.

The cooperatives bought the crude honey from members and sale to their respective union without any processing. Also the cooperatives sell honey to local consumers after semi-processing in their retailing shop.

According to the respondents, lack of member's commitment, lack of inputs, limited leadership and management capacity of management bodies, inadequate working capital, lack of government and NGO support, lack of infrastructure facilities, limited training opportunity and storage problems were the major constraints in honey production and marketing activity.

\subsection{Recommendation}

Based on the observed results, this study gives the following recommendations which are expected to contribute for reduction of the negative impacts of those identified constraints on cooperatives:

The existing management committees of cooperatives do have limited capacity to effectively lead the cooperatives. Therefore, members have to focus on electing those committed and better educated members within board of directors. The stakeholders working with cooperatives are also expected to give capacity building trainings based on the identified gaps of board of directors and the members as well.

The cooperatives are expected to improve transparency and accountability. Accordingly, they are expected to improve the participation of members on the major decisions made within the cooperative. In addition, the boards of directors are also expected to perform the leadership and to pass decisions only based on the mandate given to them on the bylaws of the cooperatives.

As the majority of members are not effectively participating or engaging themselves within their cooperatives, the honey productivity of the cooperatives is not satisfactory compared to private producers. Therefore, the cooperatives are expected to strengthen their members'participation controlling mechanism to enable them practically engaged on the day to day activity and finally contribute for better productivity.

In addition, developing organized marketing channel for cooperatives starting from the local market to the central market should be intensively done to improve the income the cooperatives expected to get. To realize this, applicable value chain analysis and market linkage work is expected to be done by the integration of governmental and NGO stake holders. Finally, besides establishing a number cooperative, it should also be expected from every stake holders in the study area to enable the cooperatives to focus on market oriented production system to be successful in their overall activity.

\section{Reference}

Adgaba N (2007). Atlas of pollen grains of major honeybee flora of Ethiopia, Holetta bee research centre, Holetta, Ethiopia

Awraris, G. S., Yemisrach, G., Dejen, A., Nuru, A., Gebeyehu, G. and Workneh, A.(2012). Honey production systems (Apismellifera L.) in Kaffa, Sheka and Bench- Maji zones of Ethiopia.

Emana, B. 2012. Cooperative movement in Ethiopia (a Paper Presented at Workshop on Perspectives for Cooperatives in Eastern Africa) Uganda: Kampala.

Emana, B., M. Nigussie. 2011. Strategizing Cooperative Development in Ethiopia. (An Unpublished Report Submitted to Agricultural Transformation Agency (ATA)). Addis Ababa, Ethiopia.

Gebre-selassie, A., T. Bekele. 2012. A review of Ethiopian agriculture: roles, policy and small- scale farming systems. In Eder, C., Kyd-Rebenburg, D. and Prammer, J., editors.

ICA (1995). Statement on the Co-operative identity, in review of international cooperation, Vol.88, No.30.

ICA (2010). International Co-operative Alliance. Retrieved 12th October, 2010, from http://www.ica.coop/

Ijere, M. O. (1992). Leading Issues in Rural Development. Enugu: Acana Publishers.

Ijere, M. O. (1992). Prospects of Nigerian Cooperatives.

Ijere, M. O. (ed.) (1991). Women in Nigerian Economy. Enugu: ACENA Publishers.

Legesse G (2013). Identification and characterization of major mono-floral honeys in Ethiopia. pp. 121-128.

Ministry of Agriculture (MoA), Federal Democratic Republic of Ethiopia (2012). Agricultural Cooperatives Sector Development Strategy 2012-2016. Retrieved from: http:/www.ata.gov.et/news/resources/sector-strategies/

Zerihun Alemayehu. (1998). Cooperatives Movement in Ethiopia, Unpublished paper presented in the National Workshop in Addis Ababa, Ethiopia. 